Int. J. Dev. Biol. 56: 49-52

doi: $10.1387 / \mathrm{ijdb} .113453 \mathrm{as}$

\title{
The past and present of planarians - An interview with Vittorio Gremigni
}

\author{
ALESSANDRA SALVETTI and LEONARDO ROSSI* \\ Department of Human Morphology and Applied Biology, University of Pisa, Italy
}

\begin{abstract}
Vittorio Gremigni is a scientific leader in the field of planarian biology with a very long historical perspective. By using electron microscopy, he contributed to the reconstruction of the phylogenesis of free living "Turbellaria", and he pioneered the study of the origin of blastema cells by using chromosomal markers. In this interview, Professor Gremigni describes the steps that moved his career towards the planarian field, the main scientific achievements he obtained and the changes that are taking place in the field. He also discusses recent progress and unanswered questions on planarian neoblasts and regeneration.
\end{abstract}

KEY WORDS: Vittorio Gremigni, planarian

\section{Introduction}

We are particularly pleased to write this interview as, a few months ago, Vittorio Gremigni retired from his long academic and scientific career. Thus, this interview provides us with the opportunity to say thanks to him for his scientific, as well as personal, constant support. In the planarian field, Vittorio Gremigni is probably one of the scientists with the longest historical perspective. He started studying planarians since his graduation thesis and approached this system through different methodologies. He answered several different questions, ranging from the systematics and phylogeny of Platyhelminthes, to the origin of blastema and the biology of neoblasts.

\section{How did you decide to study planarians?}

The destiny of my scientific career was decided in the first half of the sixties (XX century) when, following a brilliant examination, Professor Benazzi, an international authority in the field of planarian biology and cytogenetics, asked me to attend his lab to prepare my thesis. In fact, a few days later, I began my research experience with his wife Giuseppina Benazzi-Lentati studying the oogenesis of the freshwater Triclad Dugesia, where I found that meiotic oocytes (at that time considered totally alecithal) unexpectedly contain a small amount of proteinaceous yolk globules. The next step was to extend this type of investigations to other, mostly free living, Platyhelminthes, including both the so-called "archoophora" and "neoophora" through an electron microscope approach.

Only a few years after my first entry in Benazzi's Institute, following a careful reading of the comprehensive book by H.V.
Brøndsted (Brøndsted, 1969) and other reviews and original articles on the topic, I was attracted by the controversial and fascinating problem of planarian regeneration. I planned some experiments thanks to the availability in Benazzi's acquarium of some peculiar biotypes of the planarian Dugesia characterized by different chromosome sets in different cell populations (a very useful cell marker). In particular, I chose a triplo-hexaploid biotype of the sexual planarian Dugesia polychroa with triploid neoblasts, embryonic and somatic cells, diploid male germ cells and hexaploid female germ cells.

How did electron microscopy and other ground-breaking techniques transform your approach to research in the planarian field?

About fifty years ago the electron microscope technique had a great impact on the study of cell, tissue, and organ morphology, and opened a new scenario in the systematics and phylogeny of Platyhelminthes, as well as many other organisms. In my opinion, however, ultrastructural investigations were less relevant in the approach to planarian regeneration, even though they had the merit to clarify some important black points, one for all to deny the hypothesized syncytial nature of the parenchyma. The main road to obtain clear answers to the numerous questions still open in those years on the complex process of planarian regeneration was to revisit the classical experimental procedures of the first fifty years of the century: transection, grafting, X-ray treatment and so on - in particular with the aid of molecular biology techniques, an approach that some years later my dear friend Jaume Baguñà undertook successfully.

\footnotetext{
*Address correspondence to: Leonardo Rossi. Department of Human Morphology and Applied Biology, University of Pisa, Via Volta 4, 56126 Pisa, Italy. Fax: +39.050.221.9101. e-mail: leoros@biomed.unipi.it
}

Final, author-corrected PDF published online: 16 March 2012

ISSN: Online 1696-3547, Print 0214-6282 


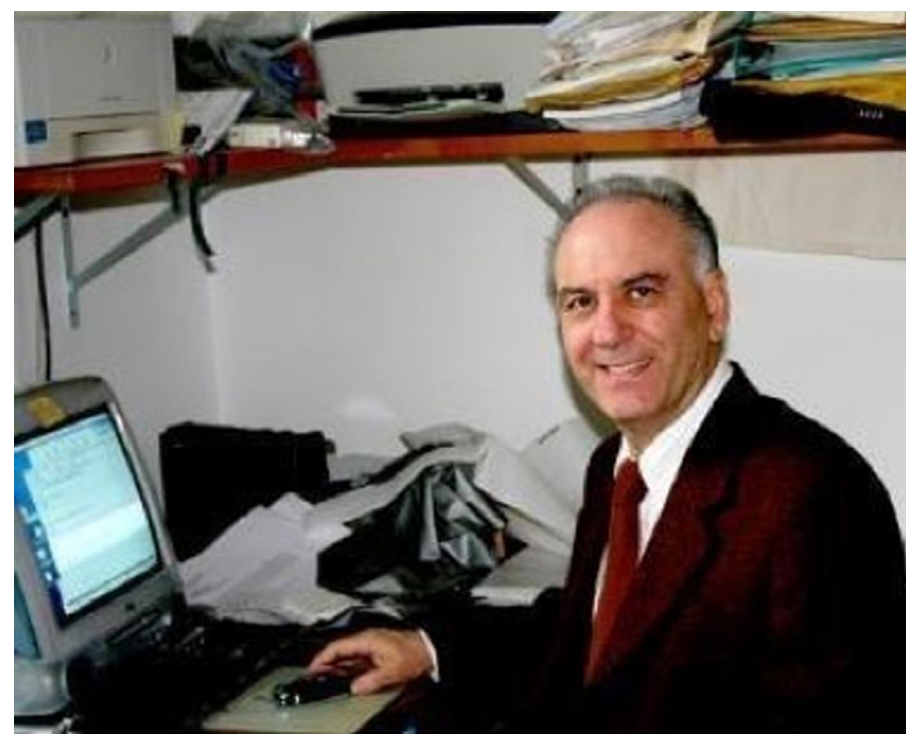

Fig. 1. Vittorio Gremigni in his office at the University of Pisa (2010).

What are your most interesting findings and what improvement has your work brought to the planarian stem cell and regeneration field?

The ultrastructural investigations on the oocytes and vitellocytes of Platyhelminthes revealed the presence of cytoplasmic inclusions with different structures, compositions and roles in these cells. Based on my and other author's findings, I suggested that these characteristics could be useful, along with the incoming molecular data, in the reconstruction of the phylogenetic relationships among free living "Turbellaria" (Gremigni, 1979, 1983, 1988, 1997; Gremigni and Falleni, 1998).

The cytological and ultrastructural research on the regeneration process performed through the use of a triplo-hexaploid biotype of $D$. polychroa demonstrated that a small percentage of male and (to a much lesser extent) female germ cells participate in blastema formation and tissue rebuilding along with a large amount of neoblasts. Thus, I suggested that regeneration in planarians is mainly due to the small undifferentiated totipotent (or pluripotent) cells, the so-called neoblasts, and, to a lesser extent, also to cells (of the germ and perhaps also of the somatic lines) at the very beginning of their differentiation process which, following a planarian transection, can interrupt their pathway towards specialization and go back to the totipotent (pluripotent) state (Gremigni and Puccinelli, 1977; Gremigni et al., 1980 a,b; Gremigni and Miceli 1980; Gremigni, 1981; Gremigni etal., 1982). These findings, obtained at the end of the seventies and very beginning of the eighties, were welcomed with very good comments by the international scientific community (not only planarian researchers). Unfortunately, I could not support my findings and suggestions with molecular data as I would have liked in those years. However, I am very happy and proud that at the very beginning of this century, this goal has been reached thanks to the admittance in my lab of two young, well learned researchers, Alessandra Salvetti and Leonardo Rossi (with other numerous Ph students) whom I thank so much also for this interview. Thus, my new research group dealt with the identification and characterization of several neoblast molecular markers, and designed and produced the first planarian microarray platform thanks to which we identified a neoblast molecular signature (Rossi et al., 2007). One of the most interesting neoblast genes that we have studied is DjPiwi-1, that was one of the first markers for a specific neoblast subpopulation of $D$. japonica to be identified (Rossi et al., 2006). Indeed, Djpiwi-1 is uniquely expressed in a group of neoblasts clustered along the dorsal body midline, preferentially anterior to the pharynx. This exclusive localization was an unexpected surprise, and paved the way to other pieces of evidence supporting neoblast heterogeneity. Indeed, we further contributed to this topic by the identification of neoblast subpopulations with different levels of tolerance to X-ray treatment (Salvetti etal., 2009). However, the specific role of the different subpopulations is still an unanswered question.

\section{What is your estimation of the changes taking place in the field of planarian stem cells and regeneration?}

The entrance into the field of planarian studies of brilliant young scientists that established new, well-funded research groups has revolutionized planarian research, bringing new excellent results to the scientific community. In recent years, several genes involved in neoblast maintenance, proliferation and differentiation have been identified, thanks to the breakthrough of new methodologies and planarian genome sequencing, thus fostering planarians as one of the most appealing model systems for stem cell and regenerative medicine research (Sánchez Alvarado, 2007; Rossi et al., 2008;
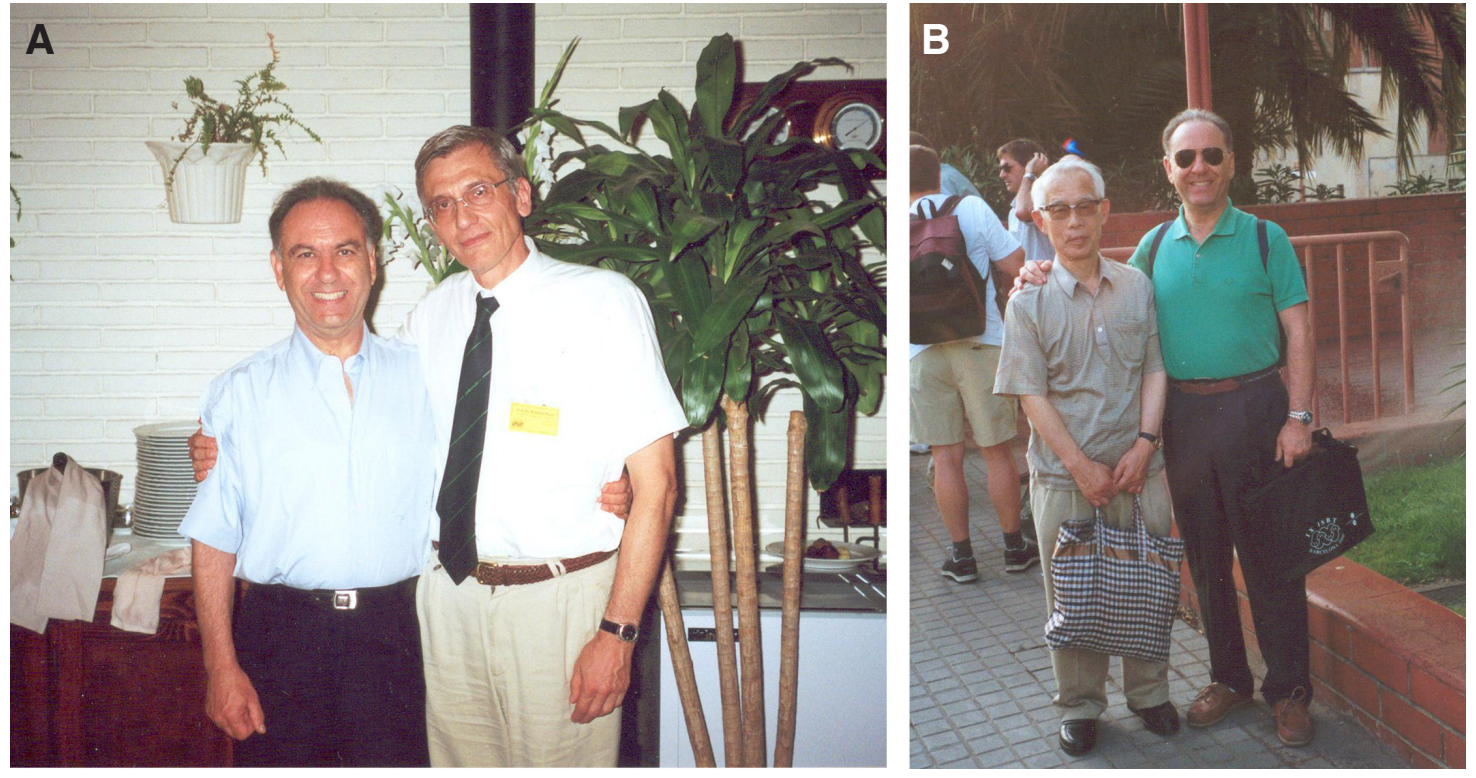

Fig. 2. Vittorio Gremigni together with his dear lamented friend Reinhard M. Riger (A) and Masahara Kawakatsu (B) at the $9^{\text {th }}$ International Symposium on the Biology of Turbellaria (Barcelona, Spain, 2000). 


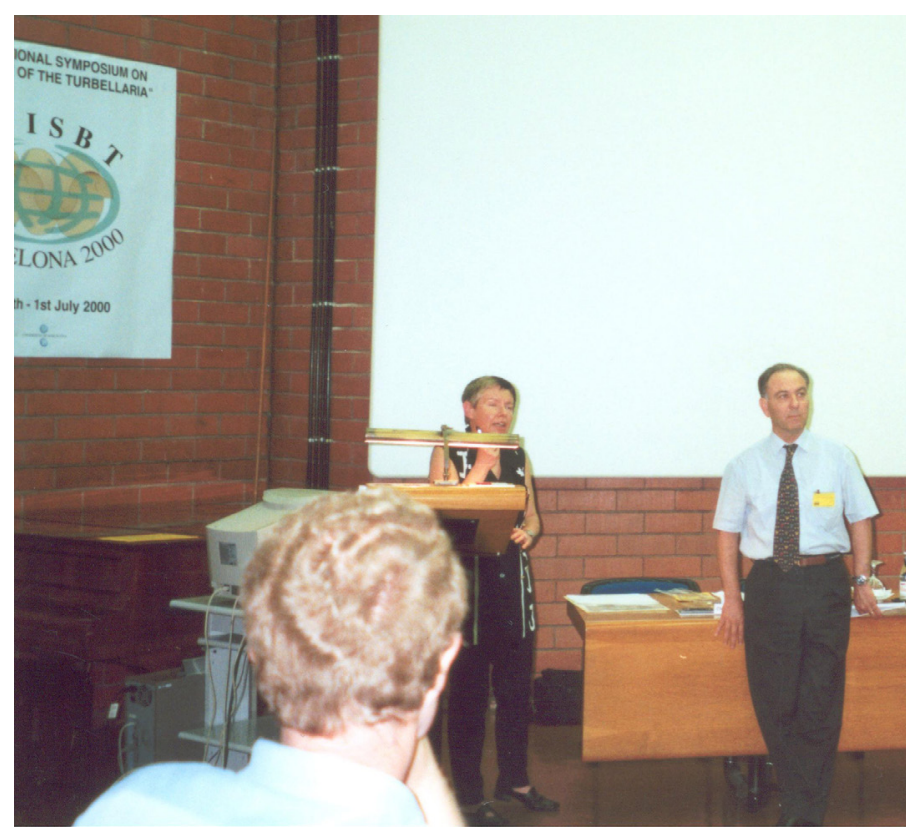

Fig. 3. Vittorio Gremigni chairing a Symposium session with Beate Sopott-Ehlers at the $9^{\text {th }}$ International Symposium on the Biology of Turbellaria (Barcelona, Spain, 2000).

Salò et al., 2009; Abril et al., 2010; Blythe et al., 2010; Hayashi et al., 2006, 2010; Shibata et al., 2010; Aboobaker, 2011; Adamidi et al., 2011; Fernández-Taboada et al., 2011; Gentile et al., 2011; Qin et al., 2011). European planarian labs recently joined together by creating EuroPlanNet (www.europlannet.org), which brings together scientists with cross-disciplinary planarian expertise. This novel form of collaboration, as well as the use of modern technologies, might represent a great opportunity for the up-grading of several European labs with a long experience in planarian research.

The planarian field is currently exploding with novel findings. What recent publication would you single out as reporting a significant achievement in planarian biology, and promoting planarians as a model system?

Well, one over all is the recent paper of the Reddien group (Wagner et al., 2011). Starting from our indication of the existence of radioresistant neoblasts capable of repopulating low-dose irradiated animal bodies (Salvetti et al., 2009), they identified an X-ray dose at which only very rare neoblasts survived, and demonstrated that these neoblasts have clonogenic capability and are able to transform a neoblast-free irradiated recipient into a genetic clone of the donor, by gradually replacing all host cells. So, Wagner et al., provided the conclusive piece of evidence that among neoblasts pluripotent adult stem cells exist, endowed with clonogenic activity.

What is, in your opinion, the most intriguing and still unanswered question about planarian neoblasts or regeneration?

In my opinion, among the still numerous black boxes, three unanswered questions deserve particular attention by the planarian scientific community. The first one concerns the heterogeneity of the neoblast population. Novel markers are indeed necessary to distinguish between the different subpopulations, in particular the lineage-restricted stem cells from true pluripotent/totipotent stem cells. The percentage of pluripotent neoblasts is still unknown. Second, although the aforementioned paper by the Reddien group suggests that pluripotent stem cells are spread throughout the ventral parenchyma, more precise information on the spatial distribution of these cells in physiological conditions is needed. The third unanswered question is strictly correlated to this point, and concerns the neoblast niche. No information is indeed available about signals that control neoblast fate. We suggested a role for neural signaling in the repopulation process that follows low dose X-ray irradiation (Salvetti et al., 2009 and Rossi et al., 2012). However, direct evidence for a role of the nervous system in neoblast regulation is still missing. I am sure that these questions will be answered in the next future, thanks to the upcoming technologies and the strengthened collaboration between planarian labs, that will allow the sharing of knowledge and expertise.

\section{References}

ABOOBAKER AA (2011). Planarian stem cells: a simple paradigm for regeneration. Trends Cell Biol. 21: 304-311.

ABRIL JF, CEBRIÀ F, RODRÍGUEZ-ESTEBAN G, HORN T, FRAGUAS S, CALVO B, BARTSCHERER K, SALÓ E (2010). Smed454 dataset: unravelling the transcriptome of Schmidtea mediterranea. BMC Genomics 11:7 31.

ADAMIDI C, WANG Y, GRUEN D, MASTROBUONI G, YOU X, TOLLE D, DODT M, MACKOWIAK SD, GOGOL-DOERING A, OENAL P, RYBAK A, ROSS E, ALVARADO AS, KEMPA S, DIETERICH C, RAJEWSKY N, CHEN W (2011). De novo assembly and validation of planaria transcriptome by massive paralle sequencing and shotgun proteomics. Genome Res. 21: 1193-1200.

BLYTHE MJ, KAO D, MALLA S, ROWSELL J, WILSON R, EVANS D, JOWETT J, HALL A, LEMAY V, LAM S, ABOOBAKER AA (2010). A dual platform approach to transcript discovery for the planarian Schmidtea mediterranea to establish RNAseq for stem cell and regeneration biology. PLoS One 5: e15617.

BRØNDSTED, H.V. (Ed.) (1969). Planarian regeneration. Pergamon Press, Oxford

FERNANDÉZ-TABOADA E, MORITZS, ZEUSCHNER D, STEHLING M, SCHÖLER HR, SALÓ E, GENTILE L (2010). Smed-SmB, a member of the LSm protein superfamily, is essential for chromatoid body organization and planarian stem cell proliferation. Development 137: 1055-1065.

GENTILE L, CEBRIÀ F, BARTSCHERER K (2011). The planarian flatworm: an in vivo model for stem cell biology and nervous system regeneration. Dis. Model Mech. 4: 12-19.

GREMIGNI V, PUCCINELLI I (1977). A contribution to the problem of the origin of blastema cells in planarians: a karyological and ultrastructural investigation. J. Exp. Zool. 199: 57-72.

GREMIGNI V (1979). An ultrastructural approach to planarian taxonomy. Systematic Zool. 28: 345-355

GREMIGNI V, MICELIC (1980). Cytophotometric evidence for cell 'transdifferentiation' in planarian regeneration. Wilhelm Roux's Archives 188: 107-113.

GREMIGNI V, MICELI C, PUCCINELLII (1980a). On the role of germ cells in planarian regeneration. I. A karyological investigation. J. Embryol. Exp. Morphol. 55: 53-63.

GREMIGNI V, MICELI C, PICANO E (1980b). On the role of germ cells in planarian regeneration. II. Cytophotometric analysis of the nuclear Feulgen-DNA content in cells of regenerated somatic tissues. J. Embryol. Exp. Morphol. 55: 65-76.

GREMIGNI, V. (1981). The problem of cell totipotency, dedifferentiation and transdetermination in Turbellaria. In The biology of the Turbellaria (Eds. E.R. Schockaert and R. Ball). Dr W. Junk Publishers, the Hague-Boston-London.

GREMIGNI V, NIGRO M, PUCCINELLI I (1982). Evidence of male germ cell redifferentiation into female germ cells in planarian regeneration. J. Embryol. Exp. Morphol. 70: 29-36.

GREMIGNI, V (1983) Platyhelminthes-Turbellaria. In Reproductive biology of invertebrates. I. Oogenesis, oviposition and oosorption. (Eds. K.G. Adiyodi, \& R.G. Adiyodi). J. Wiley \& Sons, Chichester, pp: 67-107

GREMIGNI V (1988). A comparative ultrastructural study of homocellular and heterocellular female gonads in free-living Platyhelminthes-Turbellaria. Fortschr Zool. 36: 245-261. 


\section{A. Salvetti and L. Rossi}

GREMIGNIV (1997). The evolution of the female gonad in Platyhelminthes-Turbellaria: ultrastructural investigations. Invert. Reprod. Dev. 31: 325-330.

GREMIGNI V, FALLENI A (1998). Characters of the female gonad and the phylogeny of Platyhelminthes. Hydrobiologia 383: 235-242.

HAYASHI T, ASAMI M, HIGUCHI S, SHIBATA N, AGATA K (2006). Isolation of planarian X-ray-sensitive stem cells by fluorescence-activated cell sorting. Dev. Growth Differ. 48: 371-380.

HAYASHIT, SHIBATAN, OKUMURAR, KUDOMET, NISHIMURAO, TARUI H, AGATA $K$ (2010). Single-cell gene profiling of planarian stem cells using fluorescent activated cell sorting and its "index sorting" function for stem cell research. Dev. Growth Differ. 52: 131-144.

QIN YF, FANG HM, TIAN QN, BAO ZX, LU P, ZHAO JM, MAI J, ZHU ZY, SHU LL, ZHAO L, CHEN SJ, LIANG F, ZHANG YZ, ZHANG ST (2011). Transcriptome profiling and digital gene expression by deep-sequencing in normal/regenerative tissues of planarian Dugesia japonica. Genomics 97: 364-371.

ROSSI L, SALVETTI A, LENA A, BATISTONI R, DERI P, PUGLIESI C, LORETI E, GREMIGNI V (2006). Djpiwi-1, a member of the paz-piwi gene family, defines a subpopulation of planarian stem cells. Dev. Genes Evol. 216: 335-346.

ROSSI L, SALVETTI A, MARINCOLA FM, LENAA, DERI P, MANNINI L, BATISTONI R, WANG E, GREMIGNI V (2007). Deciphering the molecular machinery of stem cells: a look at the neoblast gene expression profile. Genome Biol. 8:R62.

ROSSI L, SALVETTI A, BATISTONI R, DERI P, GREMIGNI V (2008). Planarians, a tale of stem cells. Cell Mol. Life Sci. 65: 16-23.

ROSSI, L., IACOPETTI, P. and SALVETTI, A. (2012). Stem cells and neural signalling: the case of neoblast recruitment and plasticity in low dose X-ray treated planarians. Int. J. Dev. Biol. 56: 135-142 (DOI 10.1387/ijdb.123505Ir).

SALÓ E, ABRIL JF, ADELL T, CEBRIÀ F, ECKELT K, FERNANDEZ-TABOADA E, HANDBERG-THORSAGER M, IGLESIAS M, MOLINA MD, RODRÍGUEZESTEBAN G (2009). Planarian regeneration: achievements and future directions after 20 years of research. Int. J. Dev. Biol. 53: 1317-1327.

SALVETTIA, ROSSI L, BONUCCELLI L, LENAA, PUGLIESI C, RAINALDI G, EVANGELISTAM, GREMIGNI V (2009). Adult stem cell plasticity: neoblast repopulation in non-lethally irradiated planarians. Dev. Biol. 328: 305-314.

SÁNCHEZ ALVARADO A (2007). Stem cells and the planarian Schmidtea mediterranea. C. R. Biol. 330: 498-503.

SHIBATA N, ROUHANA L, AGATA K (2010). Cellular and molecular dissection of pluripotent adult somatic stem cells in planarians. Dev. Growth Differ. 52: 27-41.

WAGNERDE, WANG IE, REDDIEN PW (2011). Clonogenic neoblasts are pluripotent adult stem cells that underlie planarian regeneration. Science 332: 811-816. 


\section{Further Related Reading, published previously in the Int. J. Dev. Biol.}

Planarian regeneration: achievements and future directions after 20 years of research Emili Saló, Josep F. Abril, Teresa Adell, Francesc Cebriá, Kay Eckelt, Enrique Fernández-Taboada, Mette Handberg-Thorsager, Marta Iglesias, M Dolores Molina and Gustavo Rodríguez-Esteban

Int. J. Dev. Biol. (2009) 53: 1317-1327

Diverse miRNA spatial expression patterns suggest important roles in homeostasis and regeneration in planarians

Cristina González-Estévez, Varvara Arseni, Roshana S. Thambyrajah, Daniel A. Felix and A. Aziz Aboobaker

Int. J. Dev. Biol. (2009) 53: 493-505

Two $\mathrm{msh} / \mathrm{msx}$-related genes, Djmsh1 and Djmsh2, contribute to the early blastema growth during planarian head regeneration

Linda Mannini, Paolo Deri, Vittorio Gremigni, Leonardo Rossi, Alessandra Salvetti and Renata Batistoni

Int. J. Dev. Biol. (2008) 52: 943-952

From Planarians to Mammals - the many faces of regeneration

Jerzy Moraczewski, Karolina Archacka, Edyta Brzoska, Maria-Anna Ciemerych, Iwona Grabowska, Katarzyna Janczyk-Ilach, Wladyslawa Streminska and Malgorzata Zimowska Int. J. Dev. Biol. (2008) 52: 219-227

Expression of DjXnp, a novel member of the SNF2-like ATP-dependent chromatin remodelling genes, in intact and regenerating planarians

Leonardo Rossi, Paolo Deri, Ilaria Andreoli, Vittorio Gremigni, Alessandra Salvetti and Renata Batistoni

Int. J. Dev. Biol. (2003) 47: 293-298

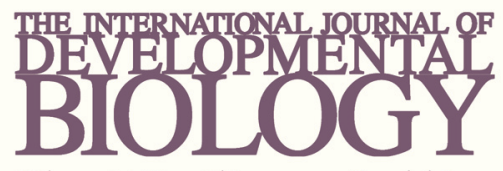

Volume 54 Nos. 6/7
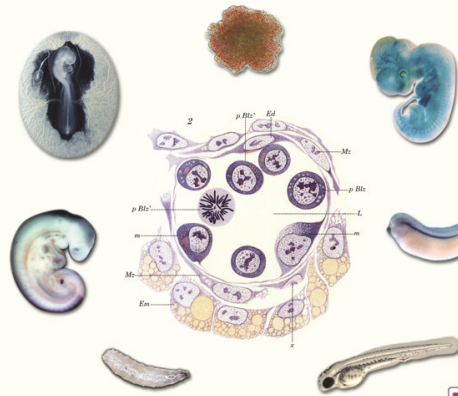

Developmental Hematopoiesis

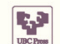

5 yr ISI Impact Factor $(2010)=2.961$

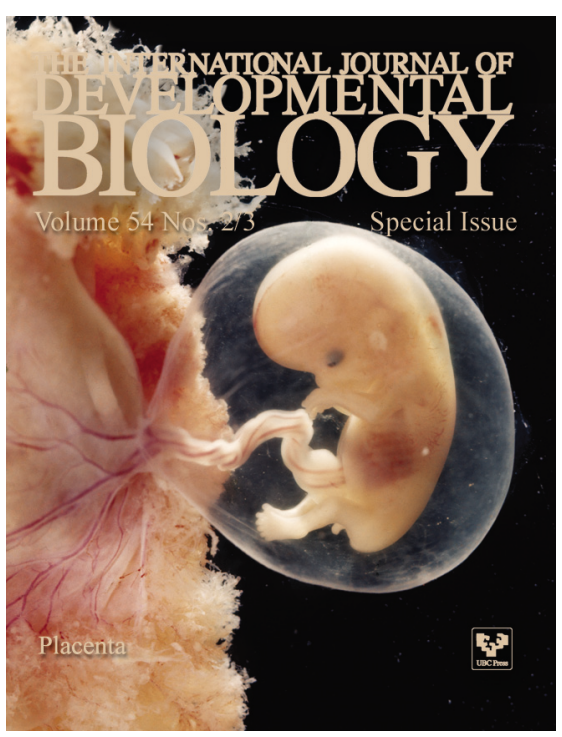

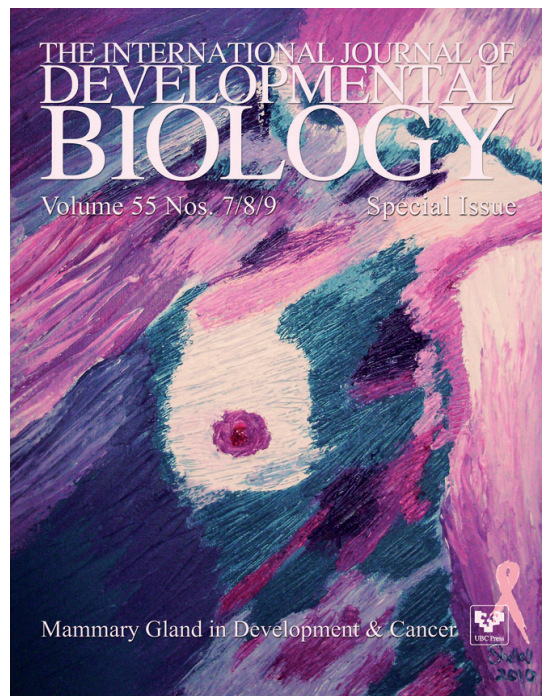

THE INTERNATIONAL JOURNAL OF DEVELOPMENTA BOUOOY

Volume 55 Nos. $4 / 5$

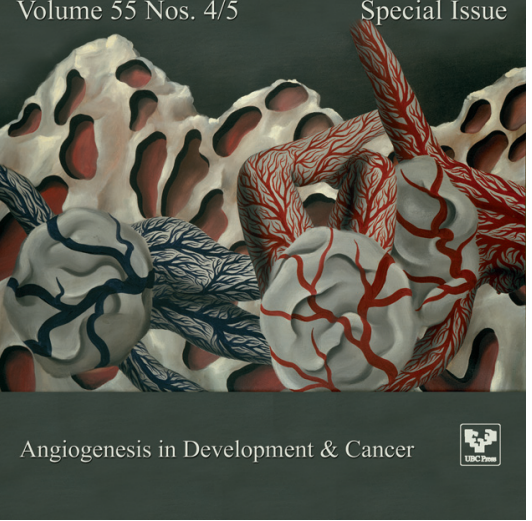

